\title{
Kadına Yönelik Şiddetle Mücadelede Cinsiyetçi ve Küfürlü Dilin Kullanılması Üzerine Bir İnceleme: Şule Çet Dayanışma Platformu Örneği
}

\author{
Ayşe AYDIN* \\ (Bu çalışma, Şule Çet ve bugüne kadar toplumsal cinsiyet eşitsizliği temelli \\ kadına yönelik şiddetin kurbanı olmuş tüm kadınlara adanmıştır).
}

$\ddot{O} \mathbf{z}$

Amaç: Bu çalışma, kadına yönelik şiddetle mücadeleye destek veren sosyal medya platformlarındaki cinsiyetçi ve küfürlü dil içeren etkileşimli iletilerin, toplumsal cinsiyet eşitliği mücadelesini engelleyici nitelikte olduğuna dikkati çekerek farkındalık yaratmayı amaçlamaktadır.

Yöntem: Bu araştırmada doküman inceleme yöntemi kullanılmıştır. Araştırma verileri, Ocak - Temmuz 2020 tarihleri arasında, kadına yönelik şiddet haberlerini paylaşan bir sosyal medya platformunun takipçilerinin gönderdikleri iletilerden elde edilmiştir. Toplanan veriler, araştırmanın amacı çerçevesinde analiz birimi olarak belirlenen kelime ve cümleler açısından incelenmiştir.

Bulgular: Araştırma kapsamında toplam 52 kadına yönelik şiddet haberi ve söz konusu haberlere ilişkin 2211 ileti incelenmiştir. İletilerin 116’sında cinsiyetçi ve küfürlü dilin kullanıldı̆̆ı tespit edilmiştir.

Sonuç: Bulgular cinsiyetçi ve küfürlü dilin kullanıldığı iletilerin sayısal açıdan fazla olmadığını göstermektedir. Bununla birlikte sosyal medya üzerinden gönderilen iletilerin; yorum, beğeni ve yeniden paylaşım yoluyla etki alanını genişlettiği dikkate alınarak, kadına yönelik şiddetle bütüncül ve çelişkisiz bir mücadele ve toplumsal cinsiyet eşitliğinin inşası için, kullanılan dile ilişkin farkındalık kazanılmasının bir gereklilik olduğu düşünülmektedir.

Anahtar Sözcükler: Kadın, şiddet, dil, sosyal medya, farkındalık.

\section{An Analysis on the Sexist and Abusive Language Used in Combating Violence Against Women: Example of Şule Çet Solidarity Platform}

\begin{abstract}
Aim: The study aims to raise awareness by drawing attention to the fact that interactive messages with sexist and abusive language on social media platforms that support the fight against violence against women are preventing the struggle for gender equality.

Method: In this study, document analysis method was used. The data were obtained from the messages sent by the followers of a social media platform that shared the news of violence against women between January and July 2020. The collected data were analyzed in terms of words and sentences determined as the unit of analysis within the scope of the study.
\end{abstract}

Results: A total of 52 news and 2211 messages related to the news on violence against women were examined. The sexist and abusive language was used in 116 of the messages.

Özgün Araştırma Makalesi (Original Research Article)

Geliş / Received: 14.05.2021 \& Kabul / Accepted: 02.09.2021

DOI: https://doi.org/10.38079/igusabder.937151

${ }^{*}$ Dr. Öğr. Üyesi, İstanbul Gelişim Üniversitesi, Sağllk Bilimleri Fakültesi, Sosyal Hizmet Bölümü, İstanbul, Türkiye,

E-Posta: ayaydin@gelisim.edu.tr_ORCID https://orcid.org/0000-0002-2059-3742 
Conclusion: The findings show that the messages with sexist and abusive language are not much in number. However, concluded that, by taking into account that social media messages can expand their sphere of influence through comments, likes and re-sharing, it is necessary to create awareness related to the abusive language for a holistic and non-contradictory struggle against violence against women and establishing gender equality.

Keywords: Women, violence, language, social media, awareness.

\section{Giriş}

Erkek egemen anlayış ve bu anlayış temelinde şekillenen erkek egemen toplum yapısı kadim bir geçmişe sahiptir. Bu yapı, her ne kadar toplumların tarihi ve sosyal, kültürel, ekonomik, siyasi vb. özelliklerine bağlı olarak toplumdan topluma farklılaşabilse de, erkeğin egemen kadının ise erkeğe bağımlı olduğu anlayışı temelinde hayata geçirilen toplumsal pratikler aracılığıyla kuşaktan kuşağa aktarılarak sürekliliğini koruyabilmiştir. Nitekim Kate Millett’in "Cinsel Politika" adlı çalışmasında dile getirdiği "Ataerkilliğin belki de en büyük ruhbilimsel silahı evrenselliği ve sürekliliğidir. Ataerkillikle karşılaştırlacak ya da onun yerine konulacak bir başka biçim hemen hemen yoktur" şeklindeki saptaması, ataerkil toplum yapısının günümüzde de evrensel geçerliliğe sahip olduğu iddiasına dayanak oluşturur niteliktedir.

Tarih boyunca değişen toplumsal koşullara uyum sağlayarak ve/veya toplumsal koşulları belirleyerek varlığını sürdürebilmesi erkek egemen kültürün bir başarısıdır. Bu sürdürülebilir başarının, büyük ölçüde, kadınların erkeklere bağımlı ve ikinci derecede bir varlık² olarak kabul edilmesi, tüm kötülüklerin kaynağı olarak görülmesi ve dahası eski metinlerde yer alan ve yüzyllarca yerleşik bir anlayış olarak toplumsal karşılı̆̆ bulunan kadın nefreti üzerine inşa edildiği söylenebilir. Nitekim Ortaçağ metinlerinde rastlanan; kadının itaatsizliğinin Havva'nın yasak meyveyi yemesiyle başladığına ve bu nedenle dünyada yaşanan tüm olumsuzluklardan Havva'nın sorumlu tutularak cezalandırılması gerektiğine ilişkin yorumlar, Ortaçă̆ Avrupa'sında kadına bakışı ve kadının toplumsal konumunu açıklar niteliktedir4. Avrupa'da 16. - 17. yüzyıllarda toplum tarafından kendileri için belirlenen rolleri oynamayı reddederek bir anlamda toplumun beklentilerini karşlamayan kadınların "cadı" olarak etiketlenip toplumdan dışlanmaları, cezalandırılmaları ve hatta yakılmalarıㄴ, kadınların kötülüklerin kaynağı olarak görüldüklerine bir başka örnek oluşturmaktadır.

"Kızların doğmaması, doğsa da yaşamaması" dileğinin yanı sıra yine kız çocukları için "eğer dünyaya gelirse, onun yerinin toprağın altı veya evinin mezara komşu olması daha hayırlıdır"6 şeklindeki düşüncelerin yer aldığı Kutadgu Bilig adlı eser ise Batı'da olduğu gibi Doğu kültüründe de kadının toplumsal konumuna ilişkin benzer bir anlayışın varlığına örnek olarak verilebilir.

Aydınlanma döneminin etkisiyle XVIII. Yüzyıl'da Batı'da, kadınlara eşitlik çağrısında bulunan sesler duyulmaya başlamıştır. Fransız Devrimi ile sonuçlanan süreçte "özgürlük, eşitlik ve kardeşlik” sloganlarıyla özdeşleşen hak arayışları, aynı zamanda kadınların eşit haklar mücadelesi için de güçlü bir dayanak oluşturmuştur. Feminizm³ kelimesinin kadınların eşit haklar mücadelesini ifade etmek için kullanılmaya başlandığı XIX. Yüzyll'ın sonlarına doğru ise kadınların özellikle örgütlü hareketler yoluyla verdikleri mücadeleler, vatandaşlık haklarına ilişkin bazı kazanımlar elde etmelerine giden yolu inşa etmiştir. Birinci dalga feminist hareket olarak bilinen bu süreç zorlu geçmiş; kadınların kamusal alanda erkeklerle eşit vatandaşlık haklarına sahip olmak için verdikleri mücadele, erkek egemen düzenin, kadın hareketini sindirmeye yönelik çeşitli girişimleriyle karşılaşmış5 ve ancak belirli ülkelerle sınırlı kalarak 
kazanılabilmiştir. Diğer ülkelerdeki kadınların bir anlamda seçme ve seçilme hakkı ile özdeşleşen vatandaşlık haklarını elde etmeleri için ise uzun bir zamanın geçmesi gerekmiştir.

Birinci dalga feminist hareketin kazanımları dünya genelinde henüz yaygınlaşmadan yine Batı'da ortaya çlkan ikinci dalga feminist hareket ise toplumsal cinsiyet kavramı üzerinden kadınlar ve erkeklere toplum tarafından uygun görülen geleneksel toplumsal cinsiyet rollerinin ve davranış kalıplarının sorgulanmasının yolunu açmıştır. Birinci dalga feminist hareket olarak tanımlanan, vatandaşlık haklarını elde etmeye yönelik verilen mücadeleler sonucunda kazanılan haklar, yazılı yasalarla güvence altına alınabilmiş ve hayata geçebilmiştir. İkinci dalga feminist hareket kapsamında toplumsal cinsiyet eşitliği kavramı üzerinden verilen günlük yaşamın her alanında kadın erkek eşitliğini talep eden hak arayışları ise; yerel, bölgesel, ulusal ve küresel düzeyde iç içe geçmiş sosyal, kültürel, ekonomik ve politik etkenler nedeniyle henüz beklenen sonuca ulaşabilmiş değildir. Zira söz konusu etkenlerin baş belirleyeni olan erkek egemen düzen; ideolojik ve zaman zaman da güç aygıtlarını kullanarak nihai hedef olan toplumsal cinsiyet eşitliğinin sağlanmasına yönelik verilen mücadeleyi engellemeye devam etmektedir.

Bununla birlikte toplumsal cinsiyet eşitliğini sağlamaya yönelik mücadele, akademik çalışmaların yanı sıra, günlük yaşamda karşılık bulan bir toplumsal harekete dönüşmüş durumdadır. 1970’li yıllarda başlayan ve 1990'lı yıllara gelindiğinde hız kazanan ikinci dalga feminist hareket sürecinde geliştirilen toplumsal cinsiyeti anaakımlaştırma stratejisi, toplumsal cinsiyet çalışmalarının daha geniş tabanlı bir katılımla yürütülmesinde etkili olmuştur. Amacı toplumsal cinsiyet eşitliğinin sağlanması olan toplumsal cinsiyeti anaakımlaştırma stratejisi, Birleşmiş Milletler Ekonomik ve Sosyal Konseyi (ECOSOC) tarafından, "tüm alanlar ve tüm düzeylerde; yasama, politika ya da programları kapsayan planlanmış herhangi bir eylemin, kadınlar ve erkekler için vereceği olası sonuçların değerlendirilmesi süreci olarak tanımlanmaktadır. Bu stratejiye göre her türlü politika ve programin tasarlanma, uygulanma, izlenme ve değerlendirme süreçlerinde söz konusu politika ve uygulamalardan kadınlarn ve erkeklerin eşit şekilde yararlanmaları sağlanmahdır”.

Nitekim bugün akademinin, sivil toplum örgütlerinin, bazı kamu kurumlarının ve medyanın, özellikle de sosyal medyanın sahiplenmesiyle toplumsal cinsiyet eşitliğini sağlamaya yönelik çalışmaların arttığı ve çeşitlendiği kolaylıkla gözlemlenebilir. Ancak bu çalışmaların toplumsal cinsiyet eşitliğinin sağlanması nihai hedefi doğrultusunda ne ölçüde etkili oldukları tartışmalıdır. Daha önce de vurgulandığı üzere erkek egemen düzen, sürekli olarak ideolojik aygıtlarını zaman zaman da güç aygıtlarını devreye sokarak toplumsal cinsiyet eşitliğini sağlamaya yönelik mücadeleleri engellemeye çalışmaktadır. Bunun yanı sıra toplumsal cinsiyet eşitliğinin sağlanmasına yönelik mücadelede, ataerkil anlayışın etkisindeki bazı iç dinamiklerden kaynaklanan nedenlerden ötürü de nihai hedefe ulaşılmasında güçlük çekildiği düşünülmektedir.

Dilin en önemli iletişim ve etkileşim araçlarından biri olarak, toplumsal cinsiyet eşitliğinin sağlanması amacı doğrultusunda kullanıl(a)maması bu nedenler arasında öncelikli bir yere sahiptir. Eril kültürün bir ürünü olan eril dil aracılığıyla toplumsal cinsiyet eşitliği üzerine fikir üretebilmenin ve erkek egemen düzeni sorgulayabilmenin zorluğu ortadadır. Eril kültür tarafından inşa edilen ve dolayısıyla cinsiyetçi ifadeler içeren günlük dilin, toplumsal cinsiyet eşitliğini sağlamaya yönelik çalışmalarda sorgulanmadan kullanılması ise mücadelesi verilen hedefe ulaşmaya değil aksine mücadele edilen erkek egemen düzenin yeniden üretilmesine hizmet etme olasılığını içinde barındırmaktadır. Bu noktada, etkileşimli iletişime olanak veren ya da tersinden ifade etmek gerekirse etkileşimli iletişimle varlık bulun sosyal medya platformlarında kullanılan dilin toplumsal cinsiyet eşitliği açısından önemi bir anlamda kendiliğinden ortaya çıkmaktadır. Zira özellikle kadının insan haklarını ve toplumsal cinsiyet 
eşitliğini savunan sosyal medya platformlarında cinsiyetçi ifadeler içeren iletilerin etkileşimli iletişime olanak verecek şekilde dolaşıma sokulmasının, toplumsal cinsiyet eşitliğinin sağlanması hedefine ulaşılmasına engel oluşturduğu düşünülmektedir.

Yukarıdaki açılamalar doğrultusunda bu çalışma, kadının insan haklarını ve toplumsal cinsiyet eşitliğini savunan sosyal medya platformlarının etkileşimli paylaşımlarında kadın cinsini aşağılayan ve kadın bedenini hedef alan cinsiyetçi ve küfürlü dilin, toplumsal cinsiyet eşitliğinin sağlanması hedefine, içeriden bir engel oluşturduğuna dikkati çekerek farkındalık yaratmayı amaçlamaktadır. Bu amaç doğrultusunda, özellikle toplumsal cinsiyet eşitsizliği temelli kadına yönelik şiddet - bundan itibaren kadına yönelik şiddet - haberlerine yer vererek kadının insan hakları savunuculuğunu yapan bir sosyal medya platformunda paylaşılan kadına yönelik şiddet haberleri, belirli bir dönem aralı̆̆ında incelenmiş; paylaşılan haberlere yapılan yorumlarda; şiddete tepki göstermek, şiddet uygulayan kişiyi kınamak amacıyla kullanılan ve doğrudan ya da dolaylı olarak kadın cinsini aşağılayan ve kadın bedenini hedef alan cinsiyetçi ve küfürlü dil içeren ifadeler tespit edilmeye çalışılmıştır. Elde edilen verilerden hareketle, kadına yönelik şiddet haberleri kapsamında yer verilen olaylara tepki göstermek amaciyla gönderilen iletilerin, kullanılan dil açısından, son noktada, ataerkil kültürün yeniden üretilmesini ve dolayısıyla ataerkil toplum düzeninin yeniden inşasını sağlamaya hizmet eden paylaşımlar olup olmadığı tartışılmaktadır.

\section{Teorik Çerçeve}

\section{Ritüel İletişim Modeli ve Kültürel Aktarım}

İletişimin ne olduğuna ilişkin farklı disiplinler tarafından farklı açıklamalar yapılmakla birikte bu açıklamaların "kişi iletişim kuramamazlık yapamaz" (one cannot not communicate) ${ }^{8}$ önkabulüne dayandığı söylenebilir. Nitekim günümüzde sosyal medya paylaşımları üzerinden insanların kendilerini gerçekleştirme çabaları dikkate alınacak olursa bu önkabulün iletişim olgusunu açıklamaya yönelik çalışmalar için geçerliliğini koruduğu kolaylıkla görülebilir. Toplumsal ilişkilerin inşası ve etkileşim ise kişiler arası kurulan iletişimin doğal sonuçları olarak ortaya çlkmaktadır.

Ancak, iletişim olgusuna duyulan ilgi, çok eski dönemlere kadar uzansa da, iletişimin insan ilişkilerini inşa etme ve etkileşime imkân vermeye ilişkin işlevinin farkına varılması daha yakın zamanlara rastlamaktadır. Nitekim iletişimle ilgili çalışmaların bazılarında ilk iletişim modeli olarak kabul edilen Aristoteles'in "Retorik" adlı eserindeki açıklamalarından XX. Yüzyıl'ın ikinci yarısına kadar geçen süre içerisinde geliştirilen iletişim modellerinde, iletişim tek taraflı; konuşmacıdan dinleyiciye ileti aktarımı şeklinde gerçekleşen düz çizgisel bir süreç olarak ele alınmıştır ${ }^{-11}$. Örneğin, Aristoteles’in açıklamaları bir tarafa bırakılacak olursa, İkinci Dünya Savaşı'ndan sonra, özellikle kitle iletişim araştırmaları için temel kaynaklardan biri olarak kabul edilen; Shannon ve Weaver tarafından geliştirilen Matematiksel İletişim Modeli’nde, iletişim basit bir doğrusal süreç olarak kabul edilmektedir ${ }^{12}$. Aynı yıllarda Laswell tarafından geliştirilen model de Fiske’nin ifadesiyle "hala doğrusaldır: iletişimi iletilerin aktarımı olarak görür12".

Kitle iletişimi açıklamaya yönelik sonraki yıllarda geliştirilen modellerde ise iletişimin bireyler arasında karşılıklı alışveriş olduğu yönündeki önkabullere daha sık rastlanmaya başlanmıştır. Buna göre, 1954 yılında Osgood ve Schramm tarafından geliştirilen Dairesel Model, iletişim sürecinin temel aktörünün sadece iletici olmadığı, alıcının da iletişim sürecinin önemli bir aktörü olduğu önkabulünden hareketle geliştirilmiştir ${ }^{11}$. İletişim ile toplumsal etkileşim arasındaki ilişki ise iletişimin dinamik bir toplumsal süreç olarak ele alındığı Gerbner Modelinde kurulmuştur ${ }^{11}$. $\mathrm{Bu}$ modelde bireyin kendisine gönderilen iletiyi olduğu gibi kabul etmediği; iletinin kabulünün 
bireyin tüm yaşamını içine alan etkileşim sonucu gerçekleştiği ileri sürülmektedir ${ }^{13}$. Bir başka ifadeyle Gerbner Modeline göre, iletişim sürecinde üretilen anlam, alıcının daha önceden edindiği bilgi ve önkabullere ve iletişim sürecinin yaşandığı ortamla ilişkilidir ${ }^{13}$.

Carey tarafından geliştirilen "İletişimin Ritüel Modeli” ise iletişimin toplum ve kültürle bağını kurarak, iletiyi yalnızca gönderme eylemi olarak değerlendiren ilk iletişim modellerinden ayrılmaktadır. Carey'e göre ritüel/törensel açıdan iletişim; "paylaşım”, "katılım”, "birlik", "dostluk/cemaat" ve "ortak bir kadere sahip olmak" gibi terimlerle bağlantılıdır. Bu çerçevede iletişimin ritüel görünümü ise toplumun korunmasına ve paylaşllan inançların temsiline yöneliktir ve dolayısıyla iletişimin orijinal hali ya da en yüksek tezahürü, bilgi aktarımında değil, anlamlı bir kültürel dünyanın inşası ve sürdürülmesinde ortaya çıkmaktadır.

Carey, bilgi aktarımı ya da tutum değişikliğine yol açma işlevini görmezden gelmemekle birlikte iletişimin sadece bu işlevlerden ibaret olmadığını vurgulayarak, iletişim eyleminin törensel görünüm ve toplumsal düzen göz önünde bulundurulmadan anlaşılamayacağını ileri sürmektedir. Carey'e göre iletişim, törensel boyut, bir başka ifadeyle, toplum ve kültür boyutları dikkate alınmadan değerlendirildiğinde, iletilerin aktarımını sağlayan bir araca indirgenmektedir. Oysaki iletişim, gerçekliğin üretildiği, üretilen gerçekliğin sürekli kılındığı, yenilendiği ve aktarıldığı sembolik bir süreçtir. Bir başka anlatımla gerçeklik verili değildir, iletişim aracılığıyla üretilmektedir; gerçekliğin üretilmesine yönelik her eylem de kişiler arası etkileşim sürecinden geçerek ritüel/törensel bir özellik kazanmaktadır. Dolayısıyla iletişim bilgi aktarımına yönelik bir eylem olmanın ötesinde; üretilen, paylaşllan, algılanan, yorumlanan, yenilenen, değiştirilen, dönüştürülen, yeniden üretilen inançların, değerlerin, kısaca sembolik biçimlerin bir temsilidir Buna göre, topluluğun ideallerinin bir anlamda yansısı niteliğinde olan sembolik biçimler, yapay olmakla birlikte yine de gerçek bir sembolik düzen yaratır. Bu düzen bilgi aktarımına değil daha çok var olanın onaylanmasına; tutumları ya da düşünceleri değiştirmeye değil var olanın özünü temsil etmeye; bir işlev yerine getirmeye değil, devam etmekte olan toplumsal süreci ortaya koymaya yöneliktir. Bu çerçevede kültür tarafından üretilen ileti, sembolik biçimlerce oluşturulan gerçekliği ilgi çekecek biçimde sunmak üzere kullanılmaktadır.

Carey, geliştirmiş olduğu Ritüel İletişim Modeli çerçevesinde ileri sürdüğü görüşlerini, gazete haberlerini inceleyerek yaptığı değerlendirmelerle savunmaktadır. Carey'e göre haber, dünyayı açıllamaya yönelik yeni bilgiler vermez. Haber, hayata genel bir biçim, düzen ve tarz veren gerçekliğin bir temsilidir. Dolayısıyla, gazete haberleri aracılı̆̆ıyla verilen bilgi yeni olmayıp; bilinenin merak uyandıran şekilde ifade edilmesinden ibarettir. Böylelikle, bir anlamda, toplum tarafından kabul gören gerçeklik, haber aracılı̆̆ıyla yeniden üretilmektedir. Dolayısıyla gazete haberleri dini ritüeller gibi, çok az değişiklik getirmelerine ve fazla bir işlevleri olmamasına karşın doyurucudurlar ve bir alışkanlık olarak tüketilirler ${ }^{14}$.

Ritüel İletişim Modeli’nin dayandığı düşünce esas alınarak bir değerlendirme yapılacak olursa, egemen kültür tarafından üretilen iletinin toplumsal etkileşim yoluyla aktarımı ve paylaşımının, toplumsal değişimden daha çok, mevcut toplumsal düzenin korunması ve sürdürülmesine olanak tanıdığı sonucuna ulaşılabilir. Bir başka ifadeyle, Ritüel İletişim Modeline göre, egemen kültürün ürünü olan iletinin, mevcut toplumsal süreci etkileyecek bir değişiklik, bir yenilik getirmek adına fazla bir işlevi olmadığı; aksine toplumdaki egemen anlayışın bireyler arasında paylaşımına olanak vererek, toplumsal düzenin korunması ve devamının sağlanması konusunda önemli bir rolü bulunduğu söylenebilir.

$\mathrm{Bu}$ noktada sosyal problem olarak tanımlanan ve ortadan kaldırılması için zihniyet değişimi üzerinden toplumsal dönüşümün gerekli olduğu düşünülen durumlarda, toplumsal düzeni 
koruyan egemen kültürün ürettiği dil kullanılarak dönüşümün nasıl gerçekleşebileceği sorusu akla gelmektedir. Soru bu çalışma kapsamında şöyle somutlaştırılabilir: Son derece aktif ve etkileşimli bir alan olan sosyal medyada haber formatında paylaşlan kadına yönelik şiddet olaylarına tepki göstermek amacıyla gönderilen bazı iletilerde örtük ya da doğrudan kadını aşağılayan küfür dilinin kullanılması, kadının insan hakları odaklı toplumsal bir sorun olan kadına yönelik şiddetle mücadeleyi nasıl etkilemektedir?

Soruya sadece bu araştırmada ulaşlan bulgular üzerinden tatminkâr bir yanıt verebilmek güç görünmekle birlikte, toplumsal cinsiyet eşitliğinin sağlanması nihai hedefi doğrultusunda yürütülen kadına yönelik şiddetle mücadelede, kadın cinsini aşă̆glayan dil ve ifadelerin kullanılmasındaki çelişkiye dikkat çekilerek farkındalığın oluşmasına katkı sağlanabileceği düşünülmektedir.

\section{Gereç ve Yöntem}

$\mathrm{Bu}$ araştırma nitel bir çalışma olup, doküman inceleme yöntemi ile gerçekleştirilmiştir. Doküman incelemesi, araştırılması planlanan olgu/olgularla ilgili bilgi içeren her türlü yazılı malzemeyi içermektedir ${ }^{15}$. Dolayısıyla doküman inceleme yöntemi, özel anlam taşıyan belgelerle sinırlı değildir; insan davranışlarının açıklanmasına yardımcı olan bütün kaynaklar doküman incelemesi için olgusal kanıt oluşturabilmektedir ${ }^{16}$. Bu çerçevede sosyal medya platformları üzerinden, kadına yönelik şiddet haberlerini kınamak amaçlı yapılan paylaşımlarda kullanılan dilin, insan davranışlarını toplum ve kültürle ilişkisi üzerinden açıklamaya imkân tanıyan olgusal kanıt niteliği taşıdığı düşünülerek araştırma için doküman inceleme yönteminin kullanılması uygun görülmüştür.

Kadına yönelik şiddet haberlerini kınamak amacıyla yapılan paylaşımların incelenmesi için sosyal medya aracı olarak Twitter, sosyal medya hesabı olarak Şule Çet Dayanışma Platformu seçilmiştir. Bu çerçevede Şule Çet Dayanışma Platformu'nun Twitter hesabı üzerinden Ocak-Temmuz 2020 tarihleri arasında paylaşılan kadına yönelik şiddet haberleri ve bu haberlere ilişkin atılan tweetler incelenerek, cinsiyetçi ve küfürlü dil içerenler tespit edilmeye çalışılmıştır. Kadına yönelik şiddet haberleri bu çalışma kapsamında kadın cinayetleri, öldürmeye teşebbüs ve yaralama ve cinsel istismar haberleri ile sinırlı tutulmuştur.

Kadına yönelik şiddet haberlerine ilişkin atılan tweetlerde kullanılan cinsiyetçi ve küfürlü dilin bu çalışma üzerinden yeniden üretilmesine aracı olmamak için, cinsiyetçi ve küfürlü dil içeren tweetler, araştırma metnine birebir aktarılmamıştır. Bunun yerine, analiz birimi olarak belirlenen cinsiyetçi ve küfürlü dil içeren kelime ve cümleler üç kategoriye ayrllarak K1, K2 ve K3 şeklinde kodlanmıştır. Buna göre atılan tweetlerde K1, erkeğin özne olduğu küfürlü dili, K2, kadını aşağılamaya yönelik küfürlü dili ve $\mathrm{K}_{3}$, doğrudan kadın bedenini hedef alan küfürlü dili ifade etmektedir.

Araştırma kapsamında toplam 52 haber ve haberlere ilişkin 2211 tweet incelenmiştir. Haberlerin 48'i kadın cinayeti, 2'si öldürmeye teşebbüs ve yaralama, 2'si cinsel istismar haberidir. Tweetlerin 118’inde cinsiyetçi ve küfürlü dilin kullanıldığı tespit edilmiştir. Şule Çet Dayanışma Platformu Twitter hesabı açık erişim olduğu için çalışmanın "Bulgular” bölümünde yer verilen 9 örnek haber ilgili hesabın sayfasından olduğu gibi alınmıştır.

Sayfalara erişim adresleri ve en son erişim tarihi “Kaynaklar” bölümünde verilmiştir. Haberlere iliş̧in cinsiyetçi ve küfürlü dil içerikli tweet atanların kullanıcı adları belirtilmemiştir. Kullanıcı adlarından hareketle tweet atanların cinsiyetleri net olarak anlaşlamamaktadır. $\mathrm{Bu}$ nedenle çalışma kapsamında incelenen tweetler, tweet atanların cinsiyeti üzerinden analiz edilmemiştir. Cinsiyetçi ve küfürlü dil içeren tweetler, örnek haberin altında, varsa, yazım hataları 
düzeltilmeden sadece küfür içeren ifadeler yukarıda belirtildiği şekilde kodlanarak, tweetin içeriğine göre sırasıyla K1, K2 ve K3 şeklinde aktarılmıştır. Atılan tweetlerin bazıları tümüyle küfürlü dil içeriklidir. Bu nedenle söz konusu tweetler ilgili örnek haberin altında küfürlü dilin içeriğine göre sadece K1, K2 ya da K3 kodu ile belirtilmiştir.

Toplanan veriler, yazar tarafından tarafsız olarak değil, nitel çalışmanın özelliği gereği, belirli bir bakış açısından yorumlanmıştır. Buna göre çalışmanın verileri, kadının insan haklarını ve toplumsal cinsiyet eşitliğini savunan bir yaklaşımla yorumlanarak tartışmaya açılmıştır.

\section{Araştırmanın Sinırlılıkları}

Araştırmanın verileri, "Yöntem” bölümünde belirtildiği üzere Ocak-Temmuz 2020 tarihleri arasında toplanmıştır. Veri analizi ve yazım sürecinde verilerin toplandığı ilgili sayfalara gerekli görüldüğü durumlarda tekrar erişim sağlanmıştır. Yazım süreci tamamlandığında, araştırma kapsamında incelenen haber paylaşımlarının tümü erişilebilir durumdadır ve son erişim tarihi metin içinde belirtilmiştir. Bununla birlikte yazım süreci sonunda, incelenen haber paylaşımlarına ilişkin atılan tweetlerde az sayıda da olsa, ilgili hesapların kapanmasından ya da ilgili tweetin silinmesinden dolayı veri kaybı yaşandığı tespit edilmiştir. Buna göre metin içinde "Örnek Haber 5 ” olarak verilen habere ilişkin atılan "Onu yetiştiren anayı (K2) ya bi bitin lan nolur" şeklindeki tweet ve bu tweete yanıt olarak başka bir takipçi tarafından atılan "Oha. Tecavüzcü müsün? Kadına şiddet haberinin altında başka bir kadını tecavüzle nasıl tehdit edebilirsin şuursuz musun?” şeklindeki tweete yazım sürecinin sonunda erişilememiştir. Söz konusu son tweete; incelenenler arasında kadına yönelik şiddetle mücadelede farkındalık oluşturma niteliği taşıyan tek tweet olması açısından önemli bulunarak "Sonuç ve Değerlendirme" bölümünde ayrıca yer verilmiştir. Ancak ilgili tweete, kullanıcı hesabının kapanmış olması ve/veya tweetin silinmiş olmasından dolayı erişilememesi önemli bir veri kaybı olarak değerlendirilmektedir.

\section{Bulgular}

\section{Ocak 2020}

9 kadın cinayeti haberine ilişkin atılan 147 tweet incelenmiştir. Atılan tweetlerin 13’ünde cinsiyetçi ve küfürlü dil kullanılmıştır.

\section{Örnek Haber 1}

“Aydın'da, 24 yaşındaki \#GamzeEsen, erkek arkadaşı tarafından darp edilip, odayı üzerine kilitleyip, benzinle evi ateşe vererek, yakılarak öldürüldü”"1.

Yukarıdaki habere ilişkin 32 tweet incelenmiştir. Cinsiyetçi ve küfürlü dil içeren tweetler:

- Vicdaninız (K1).

- $\operatorname{Cani}(\mathrm{K} 2)$.

- Bu dünyada cehennemi yaşasin şerefsiz (K2).

- Bunu yapanı neden yargılayacaksın ki? Dök benzini çak çakmağı bakalım nasıl oluyormuş. (K2). Daha da yazacaktım ama bu olayda küfürsüz kendimi ifade etmem söz konusu değil.

\section{Şubat 2020}

2 Kadın cinayeti ve 2 cinsel istismar haberine ilişkin atılan 153 tweet incelenmiştir. İncelenen tweetlerin 8'inde cinsiyetçi ve küfürlü dil kullanılmıştır. 


\section{Örnek Haber 2}

“Ankara Çubuk’ta, lise son sınıf öğrencisi 17 yaşındaki \#ŞeymaYıldız, babası tarafından "erkek arkadaşı olduğu" bahanesiyle silahla vurularak öldürüldü!”18 .

Yukarıdaki habere ilişkin 100 tweet incelenmiştir. Cinsiyetçi ve küfürlü dil içeren tweetler:

- Bu ülkenin kadınları babalarından gördüğü baskıy kimseden görmüyor. Yeri geliyor bu babalar işte böyle namus adı altında kızlarmı hayvan boğazlar gibi boğazlıyor. Ama kadınlar hala babalarma toz konduramaz. Neymiş baba çınar gibiymiş. (K1) böyle çınarı.

- Şimdi bu kader suçlusu haa! Umarm her tuvalete gidişte (K1).

- Ben senin babalı̆̆ıı (K1) aptal, (K2).

- Öyle babanin ben taaa (K3).

- Baba değil (K3)bu şerefsiz pislik.

\section{Mart 2020}

13 Kadın cinayeti haberine yönelik atılan 419 tweet incelenmiştir. 40 tweette en az 1 kez cinsiyetçi ve küfürlü dil kullanıldığı saptanmıştır.

\section{Örnek Haber 3}

"Rize'de boşandığı eski eşi Ali Rıza Havuz tarafından, sokak ortasında hunharca öldürülen \#HaticeKurt'un, katledilirken çekilmiş fotoğrafını paylaşmak yerine onu katleden bu caniyi paylaşalım ${ }^{19} . "$

Yukarıdaki habere ilişkin 311 tweet incelenmiştir. Cinsiyetçi ve küfürlü dil içeren tweetler:

- Tipine (K1) dunyayimi kurtardin bu hareketle allah belani versin!!!!

- Tipini cibiliyetini karakterini doğduğun günden bugüne aldığın nefesi (K1)

- Senin burnunu (K1)

- Senin ben tipini tiyniyetini (K1). Kahrol insallah vicdansız.

- Tipini (K1) ipe bak! Bozuk biri olduğu her tarafindan belli.

- Şeytan diyor ki git bile bile suç işle BU (K1) ile aynı cezaevine gir.

- Şerefsiz (K1)

- Virusten daha tehlikeli bunlar. Gücü sadece kadinlara yeter bu (K2) senin adamligini (K1)

- Zihniyetini (K1)

- (K1)

- Tipini (K1)

- $(K 1)$

- Tipini (K1)

- $(K 2)(K 1)$

- Tipini (K1) 
- Cibiliyetini (K1)

- Katil (K1), surata baksana

- Tipe bak(K2). Tipinde bile meymenet yok

- Tipten belli ya (K3)

- Paylassanda kadın geri mi gelecek (K3)

- (K2)

- Dostum sende adamı gömücem diye faşistlik ırkçllk yapıyorsun. Yakışmıyor. Bu (K2) yaptı̆̆ kimseye mâl edilemez.

- (K2) pislik umarim aci çekerek geberirsin korkak pislik

- Bu şey değil mi ya namustan bahsedip bunun için insan canına kuymakta behis görmeyen ama kendisi de ağzı açık ayran delisi gibi karı kız peşinde koşan (K2) evladı?!

- (K2) şerefsiz

- (K2)

- Tipinde hayır... K2

- Sana 3 ögün yemek verecek yetmiyomus gibi birde yatacak yer veren adaletin ( $\left.K_{3}\right)$ ben (K3) kafalisi nasil deli gibi bakiyor

- Anasin (K3) evladr

- Bunu gebertin gitsin bu yaşasa kime ne fayda insanlı̆̆a doğaya ne hayri olacak. Oksinen ve gida israfi bu (K3)

- Senin o cibiliyetini (K1) (K2) evladı (K3) dölü döl israfi seni

\section{Nisan 2020}

4 Kadın cinayeti haberine ilişkin 187 tweet incelenmiştir. 9 tweette en az 1 kez cinsiyetçi ve küfürlü dil kullanıldığı belirlenmiştir.

\section{Örnek Haber 4}

"Rize'de \#GamzePala aylardır takip edildiği, reddettiği, karakola şikâyet etmesine rağmen hakkında hiçbir işlem yapılmayan Savaş Dalançlar tarafından silahla vuruldu, boğazı bıçakla kesilerek öldürüldü²0.”

Yukarıdaki habere ilişkin 127 tweet incelenmiştir. Cinsiyetçi ve küfürlü dil içeren tweetler:

- Bu nasıl bir vahşet böyle öldürüp boğazın kesmek Allah belanızı versin soysuz sopsuz (K1) cehennemde yanin

- Tipine (K1)

- Tipini ayrl karakterini ap ayrl (K1)

- Böyle (K2) için yansin cehennem, bu cinayetlerin affi olmaz en ağır ceza bile En azdrr.

- Şimdi bu sevgi mi? Kendi aşağıllk kompleksi yüzünden, reddedilmenin acısıyla, toplumda insanum diye gezen bir (K2)!!! Ölmek iste öleme! 
- Bu (K2) asılmadıkça bu cinayetler durmaz K2

- Allah belalarm versin şerefsiz (K29) seni istemeyen bir kadın zorla kendine eşmi yapacaktın Farzedelim kadın istemeye istemeye kabul etti evlendin Oldu bu işmi zannedeceksin

- Şerefsiz (K2)

- Bunun gibi (K2) yüzünden özlediğim eski sevgilime özledim barışalım mı ? Yazamıyorum

\section{Mayis 2020}

6 kadın cinayeti haberiyle ilgili 230 ve 1 cinsel istismar haberiyle ilgili 64 tweet incelenmiştir. Kadın cinayetleri haberleri için atılan tweetlerin 5 ’i, cinsel istismar haberi için atılan tweetlerin ise 10’u cinsiyetçi ve küfürlü dil içermektedir.

\section{Örnek Haber 5}

“Muğla'da bu sabah, 22 yaşındaki Zeynep Şenpınar, erkek arkadaşı Selim Ahmet tarafından kaldığı evin bodrum katında bıçaklanarak öldürüldü! Genç kadının boğazında morluklar, vücudunda kesikler tespit edildi ${ }^{21}$."

Yukarıdaki habere ilişkin cinsiyetçi ve küfürlü dil içeren tweetler:

- Bayramlık agzımı açıyorum sana su veren çeşmenin borusunu (K1).

- Onu yetiştiren anayz (K2) ya bi bitin lan nolur

\section{Örnek Haber 6}

“Sinop’ta 13 yaşına kadar kızına tecavüz eden Ömer. T., duyma engelli O.N.T.'nin hamile olduğu anlaşılmasıyla ortaya çıkmış. Daha önce hamile kalan kız çocuğunun, Ömer T.'den halime olduğu DNA yoluyla tespit edilmiş! Bu pisliği unutmayın! En ağır cezayı verin²2!”

Yukarıdaki cinsel istismar haberine ilişkin cinsiyetçi ve küfürlü dil içeren tweetler: :

- Merak etmeyin cezaevinde hamile burakurlar onu (K1)

- Direkt yakın bu kansız (K1)

- (K1) evladi (K1)

- Ateşlerde yana yana kavrulasın ölmeyesin de acı çekesin (K1) kurusu!!!

- Senin ben düşünce yapını zihniyetini sıfatını (K1) (K2) çocuğu!

- (K2) çocuğu küfür değil, durum tespitidir

- (K2) çосuğu

- Kusura bakmayın ancak küfür ederek biran rahatlayacam (K2) kasığında yatmış (K2) cocuğu yavşak itoğlu it (K1) kenarı seni bana verseler 9 (K1)1 sayarım nerde kalmıştık kızını nasll be(K1) derim ayyy bu ne yaa

- Bunun (K1)kesip eline versinler. Şerefsiz (K2) çocuğu

- Ben sana bir damla su vereninde (K3) seninde (K2) çocuğu.! 


\section{Haziran 2020}

11 Kadın cinayeti haberiyle ilgili 156, 3 öldürmeye teşebbüs ve cinsel saldırı haberiyle ilgili 58 tweet incelenmiştir. Kadın cinayeti haberlerine ilişkin atılan 2 tweeti ve öldürmeye teşebbüs haberlerinden 1'i için atılan 8 tweet cinsiyetçi ve küfürlü dil içermektedir.

\section{Örnek Haber 7}

Yine bir kadın cinayeti: Kendisinden günlerdir haber alınamayan Bircan Ünal Dever’in cansız bedenine ulaşıldı. Eşi tarafından öldürülüp nehre atıldığı ortaya çıktı²3.

Yukarıdaki cinsel istismar haberine ilişkin cinsiyetçi ve küfürlü dil içeren tweetler:

- Ulan yeter Allah belanızı versin be K3 şizofrenleri

\section{Örnek Haber 8}

"Boşanmak istediği eşi Ragıp Canan tarafından, yıllarca işkence gören, canına kast edilen \#NurtaçCanan'ın, öldürülmek istenirken çekilmiş fotoğrafı paylaşmak yerine onun canına kast eden bu caniyi paylaşalım. Fail hala serbest ${ }^{24}$ !"

- Tipini (K1)

- Aort damarımı (K1). İnsanca yaşamayı ne zaman öğreneceksiniz acaba?

- Srfatın (K1) dürzüsü

- Onun ben tipini (K1) (K2)

- Gomlek giyip kıravat takınca adam sanıyorlar boylesi pisliklerin zırhı oluyor kıravat idam edin (K2)

- $(\mathrm{K} 2)$

- $(\mathrm{K} 2)$

\section{Temmuz 2020}

3 kadın cinayeti haberine ilişkin 846 tweet incelenmiştir. 24 tweette cinsiyetçi ve küfürlü dil kullanılmıştır.

\section{Örnek Haber 9}

“\#PınarGultekin'i öldüren ayrıldığı erkek cinayeti gizlemeye çalışmış. Cansız bedeni yakılmış, beton dökülmüş ve toprağa gömülmüş²5.

Yukarıdaki kadın cinayeti haberi 3 kez paylaşılmış ve toplamda habere ilişkin 797 tweet incelenmiştir. 21 cinsiyetçi ve küfür dil içerikli tweet bulunmaktadır.

- Tipini (K1)

- Şerefsiz (K1)

- Bakınız şerefsiz (K1) tam adı

- Şu (K2) papyonlu fotoğrafinı niye paylaşıyosunuz arkadaşlar?

- Tipini (K1).

- Ben böyle memleketinin taşını toprağını (K1) 
- Bazı insanlar annelerinden bağımsız olarakta (K2) olabiliyor. Pınar'ın katili de keza anadan bağımsız bir (K2). Bu ve bunun gibi anadan bağımsız (K2) yaşamayı hak etmiyor. Reddedildiğ in için öldürüyorsun bir de. Aciz (K2). Geber inşallah.

- Evlisin çocuk sahibisin birde (K2) en ağır cezayı al en ağır bedeller öde inşallah soysuz şerefsiz insan müsfettesi yaratık!!!

- (K2) (K1) suratina $s^{*}$ cayim senin adin soyun batsin idam edil insallah o ellerin tek tek kesilsin insallah kafan kopsun insallah ne istedin cicek gibi kizdan bin beteri senin basina gelsin INSALLAH -

- Tipini (K1) (K2)

- oğlum siz nasıl bi (K2) ya nasıl kansızsınız yazıklar olsun vallahi yazıklar olsun

- Ya senin ben kalbini (K1) Öldürmek nedir? Yakmak nedir? Betona gömmek nedir ? Ulan (K2) okurken kanımız çekiliyor bizim yaparken hiç mi titremiyor eliniz

- Allah belanı versin Allah belanı versin Allah belanı bin kere versin Umarım sonun aynı olur (K2)

- Allah belanızı versin (K2) yeter artık yeter

- Sen bir (K2)!

- 5-6 yll yatar çıkar bu (K2) - Görsel Kurban - - 2 Beğeni 1 retweet

- Abi inanamıyorum ya inanamıyorum! Yolda yürürken güvende değiliz (K3). Bu ne...

\section{Sonuç}

Şule Çet Dayanışma Platformu, 2018 yılında Ankara'da bir plazanın 20. katından atılarak öldürülen üniversite öğrencisi Şule Çet’in davasının devam ettiği süreçte sosyal medyada "Şule Çet için Adalet” adı altında kurulmuştur ve başta kadın cinayetleri olmak üzere kadına yönelik şiddet haberlerini çeşitli sosyal medya araçları üzerinden paylaşarak varlığını sürdürmektedir. Bu çalışmanın yapıldığı dönemde Şule Çet Dayanışma Platformu'nun twitter'da 76 binin üzerinde takipçisi bulunmaktadır. Şule Çet Dayanışma Platformu tarafından paylaşılan haberler; beğeniye, yoruma ve başkaları tarafından paylaşıma açıktır. Dolayısıyla platformla takipçiler ve takipçilerle takipçiler arasında etkileşimli iletişim mümkün olabilmektedir. Nitekim çalışma kapsamında incelenen haber paylaşımları üzerinden beğeni, yorum ve yeniden paylaşım yoluyla etkileşimli iletişim kurulduğu görülmektedir.

Eril kültür tarafından üretilmiş eril dilin bir yansıması olmasının yanı sıra, kullanıcıların kimliklerini açıkça belirtmek zorunluluğunun bulunmamasının da olası etkisiyle, sosyal medya ortamında cinsiyetçi dil ve kadını aşağılayan küfürlü dil yaygın olarak kullanılmaktadır. Twitter'in, özelliğinden dolayı, her bir tweet için sınırlı sayıda karakter kullanılarak etkileşimli iletişime imkân verdiği dikkate alınacak olursa, kişiye yönelik şiddet gibi istenmeyen olaylara tepki göstermek amaçlı atılan tweetlerin kısa ve fakat etkili olduğu düşüncesiyle cinsiyetçi ve küfürlü dilin kullanılmasının kendi içinde tutarlı ve dolayısıyla anlaşılabilir olduğu söylenebilir. Bununla birlikte, özellikle kadına yönelik şiddet olaylarını haberleştirip görünür kılarak kadının insan hakları mücadelesini desteklemeye çalışan bir oluşumun takipçileri tarafından, kadına yönelik şiddet olaylarına kadını aşağılayan küfürlü dil içerikli tweetler atılarak tepki gösterilmesi, sorgulanması gereken çok katmanlı çelişkiler içermektedir. Buna göre kadına yönelik şiddete 
kadın cinsini aşağılayan ifadeler üzerinden tepki gösterilmesi çok açık bir çelişki olmasının yanı sıra bu tür tepkilerin, etkileşimli iletişime olanak tanıyan sosyal medya araçları üzerinden yeniden ve yeniden dolaşıma sokularak son kertede kadına yönelik şiddeti sonlandırmaya değil bu şiddeti üreten kültürün beslenmesine hizmet etmeye yönelik bir nitelik kazanma olasılığı da başka bir çelişkidir.

Nitekim bu çalışma kapsamında incelenen kadına yönelik şiddet haberlerine ilişkin atılan hemen hemen tüm tweetler, içerik açısından ele alındığında şiddete, genellikle şiddetin faili üzerinden tepki gösterir nitelikte olmakla birlikte, kullanılan dil açısından ele alındığında bazıları, içerikleriyle çelişerek tepki gösterilen durumun dolaylı olarak yeniden üretilmesine hizmet eder niteliktedir.

Örneğin Haber 6 için atılan "Ben sana bir damla su vereninde (K3) seninde (K2) çocuğu.!”"26 şeklindeki tweet, habere konu şiddet olayının kabul edilemez olduğu mesajını veriyor olarak kabul edilse dahi bu mesajı vermek için kullanılan dil, aynı zamanda ve bir anlamda verilen mesajın da önüne geçerek, bu tür şiddet eylemlerinin gerçekleşmesine zemin hazırlayan ataerkil anlayışın yeniden ve yeniden üretilmesine olanak tanımaktadır. Ayrıca Haber 6 için yukarıda örnek verilen tweetin yanı sıra, Haber 2 için atılan "Öyle babanın ben taaa $\left(K_{3}\right)$ " 27 ve Haber 3 için atılan "Tipten belli ya (K3)" 28 şeklindeki tweetler, şiddetin failleri olan erkeklerin, kadını aşağılayan cinsiyetçi ve küfürlü dil kullanılarak kınandığını göstermektedir. Bu noktada kadına yönelik şiddetle mücadeleye destek veren bir oluşumun takipçileri arasında kadına şiddet uygulayan erkeğe, kadını aşağılayan cinsiyetçi küfürlü dil kullanılarak tepki gösterilmesi açık bir çelişkiyi ortaya koymaktadır. Bu çelişki ise bir erkeğin kadına benzetilmesinin, söz konusu erkek için aşağılayıcı bir durum olarak değerlendirildiği ataerkil kültürün, kadına yönelik şiddetle mücadelede çok da sorgulanmadığının dolayısıyla farkındalığın oluşmadığının bir göstergesi olarak kabul edilebilir. Nitekim araştırma kapsamında incelenen kadına yönelik şiddet haberlerine ilişkin yorumlarda kadını aşağılayan cinsiyetçi ve küfürlü dilin kullanılmasına diğer takipçiler tarafından hemen hiçbir uyarı gelmemesi de bu düşünceyi doğrular niteliktedir. İncelenen tweetler içerisinde sadece bir tweet bu konuda uyarı niteliği taşımaktadır. Örnek Haber 5 için atılan "Onu yetiştiren anayı (K2) ya bi bitin lan nolur" şeklindeki tweete bir takipçi tarafından "Oha. Tecavüzcü müsün? Kadına şiddet haberinin altında başka bir kadını tecavüzle nasıl tehdit edebilirsin şuursuz musun?” (bu tweete daha sonra erişilememiştir) şeklindeki tweet, incelenenler arasında farkındalık oluşturmaya yönelik uyarı niteliği taşıyan tek tweettir.

Kadına yönelik şiddet haberlerine tepki gösterir nitelikli tweetler sayısal olarak ele alındığında, erkeğin özne olduğu ve kadını aşă̆ılayan cinsiyetçi ve küfürlü dilin kullanıldığı tweetlerin az olduğu görülmektedir. Bununla birlikte, yeniden paylaşıma ve beğeniye açık olmaları tweetlerin etki alanını genişletmeye imkân tanımaktadır. Örneğin Haber 8 için atılan “Tipini (K1)” şeklindeki tweetin 39, Haber 9 için atılan "Bazı insanlar annelerinden bağımsız olarakta (K2) olabiliyor. Pınar'm katili de keza anadan bağımsız bir (K2). Bu ve bunun gibi anadan bağımsız (K2) yaşamayı hak etmiyor. Reddedildiğin için öldürüyorsun bir de. Aciz (K2). Geber inşallah”"7 şeklindeki tweetin 18 beğeni almış olması; erkeğin özne olduğu kadını aşağılayan cinsiyetçi küfürlü dilin söz konusu tweetler üzerinden sırasıyla en az 38 ve 18 kez onaylandığını göstermektedir. Dolayısıyla bu tür tweetler sayıca az da olsa etki faktörünün, kadına yönelik şiddetle mücadele açısından göz önünde bulundurulması önemli görülmektedir.

$\mathrm{Bu}$ noktada, sosyal medya üzerinden kadına yönelik şiddet haberlerini paylaşarak bilgi aktarımında bulunan bir oluşum ile bu oluşumun takipçileri tarafından algılanan, yorumlanan ve paylaşılan bilginin ne ölçüde kadının insan hakları savunuculuğuna destek verdiği sorusu akla gelmektedir. Acaba aktarılan bilginin algılanması, yorumlanması ve paylaşımı kadına yönelik 
şiddetin sona ermesine hizmet eder nitelikte midir yoksa bu tür etkileşimli iletişimin Carey’in belirttiği gibi tutumları ve düşünceleri değiştirmeye değil var olanın özünü temsil etmeye; bir işlev yerine getirmeye değil, mevcut toplumsal düzenin sürdürülmesine hizmet eder ${ }^{12}$ bir yönü de var mıdır? Aktarılan bilgi ve bilginin algılanma, yorumlanma ve paylaşım biçiminin, kadına yönelik şiddet sorununun ortadan kalkmasına zemin hazırlayabilecek bir toplumsal değişiklikten daha çok kadına yönelik şiddet üreten ataerkil anlayışın ve dolayısıyla ataerkil toplum düzeninin sürdürülmesine hizmet etmesi söz konusu olabilir mi? Buna göre kadına yönelik şiddet haberlerinin aktarılması, algılanması, yorumlanması ve paylaşımı kadının insan haklarının benimsenmesini ve içselleştirilmesini sağlayacak bir toplumsal değişimi gerçekleştirebilecek bir bilgi aktarımı mıdır yoksa, Carey'in vurguladığı üzere, toplumsal gerçeklik, haber aracılığıyla yeniden mi üretilmektedir ${ }^{14}$. Kadına yönelik şiddet haberleri fazla bir değişiklik getirmemekte buna karşın doyurucu olup bir alışkanlık olarak tüketilmekte midir?

Kuşkusuz bu sorulara araştırma kapsamında elde edilen verilerden hareketle doyurucu yanıtlar verebilmek olası değildir. Ayrıca kadına yönelik şiddetle mücadelede sosyal medyanın yoğun bir biçimde kullanıldığı dikkate alındığında bu mücadelenin farkındalık yaratmadığını ileri sürmek çok da gerçekçi olmayacaktır. Bununla birlikte etkileşimli iletişimde kullanılan dilin bütüncül ve çelişkisiz bir mücadele için uygun bir dil olup olmadığının sorgulanması önemli bulunmaktadır. Çalışmanın "Giriş" bölümünde de belirtildiği gibi, ataerkil kültür ve değerlerle kuşatılmış bir halde ve bu kültürün dilini kullanarak kadına yönelik şiddet üreten ataerkil zihniyetle mücadele edebilmek kolay değildir. Bu noktada içinde zihniyet değişimi barındırdı̆̆ı ön kabulünden hareketle, etkileşimli iletişim dilini de kapsayacak şekilde çok yönlü ve sürdürülebilir bir farkındalığın oluşması ve desteklenmesinin önemi kendiliğinden ortaya çıkmaktadır. Çok yönlü ve sürdürülebilir farkındalık yaratmadan verilen kadına yönelik şiddetle mücadelenin ise kadına yönelik şiddet üreten ve kadının insan haklarını görünmez kılan ataerkil anlayış temelinde şekillenen toplumsal yapının yeniden inşasına hizmet etmesi kaçınılmaz bir sonuç olacaktır. Bu noktada bir taraftan kadına yönelik şiddetle mücadele edilirken bir taraftan da mücadele yöntemlerinin, mücadelenin nihai hedefi olan toplumsal cinsiyet eşitliğini sağlama konusunda ne ölçüde etkili olduğunun sorgulanması, çok boyutlu ve sürdürülebilir farkındalığın oluşması açısından önemli bulunmaktadır.

\section{KAYNAKLAR}

1. Millet K. Cinsel Politika. S. Selvi, çev. 2. baskı. İstanbul: Payel Yayınevi; 1987.

2. Beauvoir S. Kadın. İkinci Cins Bağımsızlı̆̆a Doğru. Onaran B, çev. 8.baskı. İstanbul: Payel Yayınevi; 1993.

3. Garzón-Pérez JS. Historia Del Feminismo. Segunda edición. Madrid: Catarata; 2012.

4. Weisl JA. "Quiting” Eve: Violence Against Women in the Canterbury Tales. In: Roberts A, ed. Violence Against Women in Medieval Texts. Gainesville, Fla: University Press of Florida; 1998:115-136.

5. Ertürk Y. Sinur Tanımayan Şiddet. Paradigma, Politika ve Pratikteki Yönleriyle Kadına Şiddet Olgusu. İstanbul: Metis Yayınları; 2015.

6. Doğan İ. Dünden Bugüne Türk Ailesi. Sosyolojik Bir Değerlendirme. Ankara: Atatürk Kültür Merkezi Yayını 369; 2009.

7. Aydın A. Toplumsal Cinsiyet Kavramının Kullanımı Üzerine Bir Değerlendirme. Almıla. 2016;24:122-125. 
8. Watzlawick P, Beavin JH, Jackson DD. Pracmatics of Human Communication: A Study of International Patterns, Pathologies, and Paradoxes. New York: W. W. Norton \& Company, Inc.; 1967.

9. Usluata A. İletişim. İstanbul: İletişim Yayınları; 1984.

10. Tekinalp Ş. Uzun Ş. İletişim Araştırmaları ve Kuramları. İstanbul: Derin Yayınları; 2004.

11. McQuail D, Windhal S. Kitle İletişim Modelleri. Yumlu K, çev. Ankara: İmge Kitabevi Yayınları; 1997.

12. Fiske J. İletişim Çalışmalarına Giriş. İrvan S, çev. Ankara: Pharmakon Yayınevi; 2013.

13. Lazar J. İletişim Bilimi. Anık C, çev. Ankara: Vadi Yayınları; 2001.

14. Carey WC. Communication As Culture. Essays on Media and Society. New York: Routledge; 1992.

15. Yıldırım A, Şimşek H. Sosyal Bilimlerde Nitel Araştırma Yöntemleri. Üçüncü Baskı. Ankara: Seçkin Yayıncılık; 2003.

16. Mayring P. Nitel Araştırmaya Giriş. Gümüş A, Durgun MS, çev. Adana: Baki Kitabevi; 2000.

17. https://twitter.com/suleicinadalet/status/1220342902829862917. Son Erişim Tarihi 14 Mayıs 2021.

18. https://twitter.com/suleicinadalet/status/1225687791293517824. Son Erişim Tarihi 14 Mayıs 2021.

19. https://twitter.com/suleicinadalet/status/1243789372929052672/photo/1. Son Erişim Tarihi 14 Mayıs 2021.

20. https://twitter.com/suleicinadalet/status/1250709719989325831/photo/1. Son Erişim Tarihi 14 Mayss 2021.

21. https://twitter.com/suleicinadalet/status/1264494236524781576/photo/1. Son Erişim Tarihi 14 Mayıs 2021.

22. https://twitter.com/suleicinadalet/status/1261647217867268096/photo/1. Son Erişim Tarihi 14 Mayıs 2021.

23. https://twitter.com/suleicinadalet/status/1277292137957265413/photo/1. Son Erişim Tarihi 14 Mayıs 2021.

24. https://twitter.com/suleicinadalet/status/1273940360461418498/photo/1. Son Erişim Tarihi 14 Mayıs 2021.

25. https://twitter.com/suleicinadalet/status/1285472868969701377/photo/1. Son Erişim Tarihi 14 Mayıs 2021.

26. https://twitter.com/search?q=\%E2\%80\%9CBen\%20sana\%2obir\%20damla\%20su\%20vere ninde\&src=typed query. Son Erişim Tarihi 14 Mayıs 2021.

27. https://twitter.com/Gkhnbjko7Guler/status/1225724724963106816. Son Erişim Tarihi 14 Mayıs 2021.

28. https://twitter.com/suleicinadalet/status/1243789372929052672. Son Erişim Tarihi 14 Mayıs 2021. 